\title{
PENGARUH MOTIVASI DAN KEPEMIMPINAN TERHADAP KINERJA KARYAWAN PADA PT. BANK BTN BATAM
}

\author{
Dhenny Asmarazisa \\ Dosen Tetap Prodi Manajemen Universitas Riau Kepulauan Batam
}

\begin{abstract}
ABSTRAK
Penelitian ini bertujuan untuk mengetahui Pengaruh Motivasi dan Kepemimpinan terhadap Kinerja Karyawan pada PT. Bank BTN Batam. Penelitian ini dilakukan dengan pendekatan survei yang terdiri dari Variable Motivasi dan Kepemimpinan (X) dan Kinerja Karyawan (Y), untuk membuktikan pengaruh motivasi dan kepemimpinan terhadap kinerja karyawan, maka penulis mengumpulkan data dengan cara penyebaran kuisioner sebanyak 50 orang responden sebagai sampel yang diambil dari karyawan PT. Bank BTN Batam, data yang terkumpul melalui kuisioner diolah dengan menggunakan aplikasi program Statistical Product and Service Solution (SPSS) versi 21, hasil penelitian menunjukan bahwa motivasi dan kepemimpinan secara bersama - sama berkontribusi memberikan pengaruh positif dan signifikan terhadap kinerja karyawan sebesar $68,5 \%$, adapun sisanya sekitar 31,5\% dipengaruhi oleh faktor lain, hasil analisis regresi secara parsial menunjukan bahwa variabel motivasi dan kepemimpinan secara individual mempunyai pengaruh positif dan signifikan terhadap kinerja karyawan.
\end{abstract}

\section{LATAR BELAKANG}

Untuk dapat mencapai tujuan perusahaan/instansi diperlukan suatukepemimpinan yang baik, yaitu dengan memanfaatkan atau menggerakkan sumber-sumber yang tersedia, salah satunya adalah sumber daya manusia agar tetap loyal, untuk meningkatkan kinerjanya diperlukan kepemimpinan yang baik. Manajemen Sumber Daya Manusia secara implisit menyamakan manusia dengan benda yang dapat diatur dan dikelola tidak sepenuhnya salah, tetapi ini mereduksi hakekat kemanusiaan menjadi sekedar mahkluk yang berdimensi fisik serta mengabaikan dimensi lainnya seperti sosial emosional, mental dan spiritual. Ketiga dimensi terakhir disebut ini hanya bisa didekati dengan kepemimpinan.

Peningkatan kinerja karyawan dapat tercapai apabila perusahaan/instansi mampu memberikan motivasi terhadap kinerja karyawan untuk membentuk iklim kerja yang baik sehingga terbentuk kinerja yang tinggi. Memberikan motivasi adalah pekerjaan yang dilakukan oleh seorang pemimpin/manager dalam memberikan inspirasi, semangat dan dorongan kepada orang lain untuk mengambil tindakan.

Melihat kenyataan tersebut, sudah saatnya dapat lebih banyak memberikan kesempatan kepada karyawan mengembangkan sumber daya manusia agar lebih berprestasi dalam melaksanakan tugas pelayanan, terlebih lagi dalam rangka otonomi daerah. Dengan demikian kiranya perlu dirumuskan secara mendalam, usaha-usaha secara terpadu dan berkesinambungan melalui penerapan pengaruh kepemimpinan dan motivasi terhadap kinerja karyawan yang dikembangkan di lingkungan PT. Bank BTN Batam. 
Pembatasan masalah dalam penelitian ini adalah hanya sebatas menguji variabel kepemimpinan, motivasi dan kinerja karyawan. Sedangkan variabel lainnya yang berpengaruh terhadap kinerja karyawan tidak diuji. Penelitian dilakukan pada PT. Bank BTN Cabang Batam.

Berdasarkan uraian di atas, maka penulis dapat merumuskan permasalahan dalam penelitian ini adalah sebagai berikut :

1. Apakah motivasi berpengaruh terhadap kinerja karyawan pada PT. Bank BTN Cabang Batam?

2. Apakah kepemimpinan berpengaruh terhadap kinerja karyawan pada PT. Bank BTN Cabang Batam ?

3. Apakah kepemimpinan dan motivasi kerja secara bersama-sama berpengaruh terhadap kinerja karyawan pada PT. Bank BTN Cabang Batam?

Sesuai dengan rumusan masalah dan tujuan yang telah ditetapkan, maka manfaat yang diharapkan dari penelitian ini adalah :

1. Dapat memberikan masukan dan sebagai informasi tambahan bagi karyawan mengenai pengaruh motivasi dan kepemimpinan terhadap kinerja karyawan guna menambah ilmu pengetahuan dan untuk mengetahui penerapan sebenarnya.

2. Menambah pengetahuan penulis sehubungan dengan manajemen sumber daya manusia di Fakultas Ekonomi Universitas Riau Kepulauan (UNRIKA) khususnya dalam penerapan pengaruh kepemimpinan dan motivasi terhadap kinerja karyawan pada PT. Bank BTN Cabang Batam.

3. Sebagai bahan masukan bagi pimpinan pada PT. Bank BTN Cabang Batam, sehingga pimpinan dapat mengambil tindakan atau motivasi yang diperlukan.

4. Karyawan dapat mengetahui apa yang menjadi hak dan apa yang menjadi hak dan apa yang menjadi kewajiban sesuai dengan pekerjaannya.

5. Sebagai bahan informasi dan referensi serta kajian dan acuan bagi para penulis berikutnya serta pihak lain yang membutuhkannya pada masa yang akan datang.

\section{KERANGKA TEORI}

Kepemimpinan adalah kemampuan para pemimpin mempengaruhi para bawahannya sehingga para bawahannya bersedia secara sukarela melaksanakan pekerjaan sesuai dengan keinginan pemimpinnya. Kepemimpinan dapat diartikan sebagai kemampuan mendorong sejumlah orang (dua orang atau lebih) agar bekerja sama dalam melaksanakan kegiatan-kegiatan yang terarah pada tujuan bersama.

Struktur Organisasi adalah kerangka atau susunan unit atau satuan kerja atau fungsi - fungsi yang dijabarkan dari tugas atau kegiatan pokok suatu organisasi dalam usaha mencapai tujuannya. Setiap unit mempunyai posisi masing-masing sehingga ada unit yang berbeda jenjang atau tingkatannya dan ada pula yang sama jenjang atau tingkatan antara satu dengan yang lainnya.

Kepemimpinan menurut Ralph M. Stogdill (Wahjosumidjo 2004) didefinisikan sebagai sarana pencapaian tujuan yang dimaksudkan dalam hubungan ini pemimpin merupakan seseorang yang memmiliki suatu program dan yang berperilaku secara bersama-sama dengan anggota-anggota kelompok dengan mempergunakan cara atau gaya terentu. Sehingga kepemimpinan mempunyaui peranan sebagai kekuatan dinaik yang mendorong, memotivasi dan mengkoordinirkan organisasi dalam mencapai tujuan yang telah ditetapkan.

Dewasa ini terdapat bermacam-macam teori tentang kepemimpinan yang di dalamnya terdapat perbedaanperbedaan dalam pendapat dan metologi-metologi, keterangan dan kesimpulan. Ada beberapa macam teori-teori kepemimpinan menurut Stephen P. Robbins (2008) :

Teori Sifat (Trait Theory) Membedakan para pemimpin dari mereka yang bukan pemimpin dengan cara berfokus pada berbagai sifat dan karakteristik pribadi. Suatu kajian yang komprehensif mengenai literature kepemimpinan, dengan mengacu pada model Lima Besar, menemukan bahwa ekstra versi merupakan sifat terpenting dari pemimpin yang efektif. Tetapi, hasil menunjukan bahwa ekstraversi lebih terkait dengan kemunculan pemimpin alih-alih efektifitasnya. Usaha-usaha penelitian untuk memetakan sifat-sifat kepemimpinan mengarah pada jalan buntu. Sebagai contoh, sebuah tinjauan dari akhir tahun 1960-an mengenai 20 kajian yang berbeda mengidentifikasikan hamper 80 sifat kepemimpinan, tetapi hanya 5 darinnya yang sama dalam empat penyelidiki. Pada tahun 1990-an, setelah banyak kajian dan analisis, kira-kira hal yang terbaik yang bisa dikatakan adalah 
sebagian besar pemimpin tidak seperti orang lain, tetapi sifat-sifat tertentu yang terpetakan sangat berbeda dari tinjauan yang lain.

Teori Perilaku (Behavioral Theory) Kepemimpinan mempunyai kemampuan untuk Berdasarkan bukti yang ada, teori perilaku seperti halnya teori sifat, member tambahan pemahaman mengenai kepemimpinan yang efektif. Pra pemeimpi yang memiliki sifat-sifat tertentu dan yang menampilkan perilaku tenggang rasa (consideration) dan disiplin dalam kerja (structuring) memang lebih efektif.

Teori Situasional Hersey dan Blanchard, Paul Hersey dan Ken Blanchard telah mengembangkan sebuah model kepemimpinan yang memperoleh banyah pengikut setia di kalangan spesialis pengembangan manajemen. Model ini disebut teori kepemimpinansituasional (situasionla leadership theory). Kepemimpinan situasional adalh sebuah teori yang kemungkinan berfokus pada para pengikut. Kepemimpinan yang berhasil dicapai dengan cara memilih gaya kepemimpinan yang benar. Penekanan pada para pengikut dalam efektivitas kepemimpinan mencerminkan realitas bahwa para pengikutlah yang menerima atau menolak pemimpin tersebut. Pada dasarnya SLT menganggap hubungan pemimpin dengan pengikut dapat disamakan dengan hubungan antara orang tua dan anak di dalam keluarga. Seperti contoh orang tua melepaskan kendali mereka ketika anak sudah menjadi leih dewasa dan bertanggung jawab.

Teori Pertukaran Pemimpin dan Anggota, Teori ini menyatakan bahwa karena tekanan waktu, pemimpin membangun suatu hubungan khusus dengan kelompok kecil dari para pengikutnya. Mereka membentuk kelompok baru dengan anggota yang dipercaya. Mereka mendapatkan lebih sedikit waktu dari pemimpin, lebih sedikit penghargaan dan memiliki hubungan yang didasarkan pada interaksi formal.

Teori Jalan-Tujuan (path-goal theory), Teori ini merupakan tugas pemimpin untuk memberikan informasi, dukungan, atau sumber-sumber daya lain yang dibutuhkan kepada para pengikut atau bawahan agar mereka bisa mencapai berbagai tujuan mereka. Istilah jalan-tujuan berasal dari keyakinan bahwa para pemimpin yang efektif semestinya bisa menunjukan jalan guna membantu pengikut-pengikut mereka untuk mendapatkan hal-hal yang mereka butuhkan demi mencapai tujuan kerja dan mempermudah perjalanan serta menghilangkan berbagai rintangannya.

Hasibuan (2008), motivasi adalah pemberian daya pengerak yang menciptakan kegairahan seseorang agar mereka mau bekerja sama, bekerja efektif dan terintegrasi dengan segala daya upayanya untuk mencapai kepuasan. Jadi motivasi mempersoalkan bagaimana caranya mengarahkan daya dan potensi bawahannya, agar mau bekerja sama secara produktif, berhasil mencapai dan mewujudkan tujuan yang telah ditentukan. Pentingnya motivasi karena motivasi adalah hal yang menyebabkan, menyalurkan, dan mendukung perilaku manusia, supaya mau bekerja giat dan antusias mencapai hasil yang optimal.

Motivasi menurut Hasibuan (2008) adalah pemberian daya gerak yang menciptakan kegairahan kerja seseorang agar mereka mau bekerjasama, bekerja efektif dan terintegrasi dengan segala upayanya untuk mencapai kepuasan.

Motivasi adalah keadaan dalam pribadi seorang yang mendorong keinginan individu melakukan kegiatan-kegiatan tertentu untuk mencapai tujuan Buhler, (2004) memberikan pendapat tentang pentingnya motivasi sebagai berikut : "motivasi pada dasarnya adalah proses yang menentukan seberapa banyak usaha yang akan dicurahkan untuk melaksanakan pekerjaan. Motivasi atau dorongan untuk kerja ini sangat menentukan bagi tercapainya sesuatu tujuan, maka manusia harus dapat menumbuhkan motivasi kerja setinggi-tingginya bagi karyawan dalam perusahaan.

Pengertian motivasi erat kaitannya dengan timbulnya sesuatu kecenderungan untuk berbuat sesuatu guna mencapai tujuan. Ada hubungan yang kuat antara kebutuhan motivasi, perbuatan, atau tingkah laku, tujuan dan kepuasan. Karena setiap perubahan senantiasa berkat adanya dorongan motivasi. Motivasi timbul karena pencapaian tujuan tertentu. Apabila tujuan telah tercapai maka akan tercapai kepuasan dan cenderung untuk diulang kembali sehingga lebih kuat dan mantap. 
Hirarki kebutuhan menurut maslow (Robbins, 2008) bahwa motivasi didasarkan atas tingkat kebutuhan yang disusun menurut prioritas kekuatannya. Apabila kebutuhan pada tingkat bawah telah dipenuhi maka kondisi ini menimbulkan kebutuhan untuk memenuhi perilaku yang menuntut kebutuhan yang lebih tinggi. Tingkat kebutuhan terbawah adalah kebutuhan fisiologis atau kebutuhan untuk hidup terus misalnya kebutuhan untuk makan, tidur, udara dan sebagainya. Setelah kebutuhan tersebut terpenuhi, maka kebutuhan selanjutnya adalah kebutuhan keselematan dan keamanan.

Dalam mengukur tingkat motivasi kerja anggota, indicator yang akan diteliti adalah perilaku anggota yang mencerminkan motivasi mereka dalam melakukan pekerjaan yang meliputi : kesungguhan dan keseriusan dalam meyelesaikan pekerjaan tanggung jawab terhadap diri sendiri, atasan dan sesame anggota, kebutuhan akan prestasi dan hasil kerja yang baik : ketabahan akan kejujuran dalam bekerja dan keuletan atau kekhawatiran jika menghadapi kegagalan

Motivasi merupakan satu penggerak dari dalam hati seseorang untuk melakukan atau mencapai suatu tujuan. Motivasi juga bisa dikatakan sebagai rencana atau keinginan untuk menuju kesuksesandan menghindari dari kegagalan dalam kehidupan. Dengan kata lain motivasi adalah sebuah proses untuk mencapai suatu tujuan. Seseorang yang mempunyai motivasi berarti ia telah mempunyai kekuatan untuk memperoleh kesuksesan dalam kehidupan.

Motivasi dapat berupa motivasi intrinsic dan ekstrinsic. Motivasi yang bersifat intrinsic adalah mana kala sifat pekerjaan itu sendiri yang membuat seorang termotivasi, orang tersebut kepuasan dengan melakukan pekerjaan tersebut bukan karena rangsangan lain seperti status ataupun uang atau bisa juga dikatakan seorang melakukan hobbynya. Sedangkan motivasi ekstrinsik adalah manakala elemen - elemen diluar pekerjaan yang melekat di pekerjaan tersebut menjadi factor utama yang membuat seorang termotivasi seperti staus ataupun kompensasi.

Banyak teori motivasi yang dikemukakan oleh para ahli yang dimaksudkan untuk memberikan uraian yang menuju pada apa sebenarnya manusia dan manusia akan dapat menjadi seperti apa. Landy dan Beeker membuat pengelompokan pendekatan teori movitasi menjadi 5 kategori yaitu : Teori Kebutuhan, teori penguatan, teori keadilan, teori harapan, dan teori penetapan sasaran.

Teori Motivasi Abraham Maslow (1943-1970) Abraham Maslow (1943-1970) mengemukakan bahwa pada dasarnya semua manusia memeliki kebutuhan pokok. Ia menunjukkannya dalam lima tingkatan yang berbentuk pyramid, orang memulai dorongan dari tingkat terbawah. Lima tingkat kebutuhan itu dikenal dengan sebutan Hirarki Kebutuhan Maslow, dimulai dari kebutuhan biologis dasar sampai motif fisiologis yang lebih komples; yang hanya akan penting setelah kebutuhan dasar terpenuhi. Kebutuhan pada peringkat berikutnya menjadi penentu tindakan yang penting.

Kebutuhan fisiologis (rasa lapar,rasa haus dan sebagainya). Kebutuhan rasa aman (merasa aman dan terlindung, jauh dari bahaya). Kebutuhan akan rasa cinta dan rasa memiliki (berafiliasi dengan orang lain, diterima dan memiliki). Kebutuhan akan penghargaan (berprestasi, berkompetensi dan mendapat dukungan serta pengakuan). Kebutuhan aktualisasi diri (kebutuhan kognitif, mengetahui, memahami, dan menjelajahi, kebutuhan setetika. Keserasian, keteraturan, dan keindahan, kebutuhan aktualisasi diri, mendapatkan kepuasan diri dan menyadari potensinya)

Bila makan dan rasa aman sulit diperoleh, pemenuhan kebutuhan tersebut akan mendominasi tindakan seseorang dan motif-motif yang lebih tinggi akan menjadi kurang signifikan, orang hanya akan mempunyai waktu dan energy untuk menekuni minat estetika dan intelektual, jika kebutuhan dasarnya sudah dipenuhi dengan mudah. Karya seni dan karya ilmiah tidak akan tumbuh subur dalam masyarakat yang anggotanya masih harus bersusah payah mencari makan, perlindungan dan rasa aman.

Teori Motivasi Herzberg (1966)

Menurut Herzberg (1966) ada dua jenis factor yang mendorong seseorang untuk berusaha mencapai kepuasan dan menjauhkan diri dari ketidakpuasan, dua factor itu disebutnya factor hygiene (factor ekstrinsik) dan 
factor motivator (factor intrinsic). Factor hygiene memotivasi seseorang yang keluar dari ketidakpuasan, termasuk didalamya adalah hubungan antar manusia, imbalan, kondisi lingkungan dan sebagainya (factor Ekstrinsik). Sedangkan factor motivator memotivasi seorang untuk berusaha mencapai kepuasan, yang termasuk didalamnya adalah achievement, pengakuan, kemajuan tingkat kehidupan, dsb (factor intrinsic).

\section{Teori Motivasi Douglas Mcgregor}

Douglas Mcgregor mengemukakan dua pandangan manuasia yaitu teori x (negative) dan teori y (positif), menurut teori $\mathrm{x}$ empat pengandaian yang dipegang manajer yaitu :

Karyawan secara inheren tertanam dalam dirinya tidak menyukai kerja. Karyawan tidak menyukai kerja harus diawasi atau diancam dengan hukuman untuk mencapai tujuan. Karyawan akan menghindari tanggung jawab. Kebanyakan karyawan menaruh keamanan diatas semua factor yang dikaitkan dengan kerja.

Kontras dengan pandangan negative ini mengenai kodrat manusia ada empat teori y yaitu :

Karyawan dapat memandang kerjasama dengan sewajarnya seperti instirahat dan bermain. Orang akan menjalankan pengarahan diri dan pengawasan diri jika mereka komit pada sasaran. Rata-rata orang akan menerima tanggung jawab. Kemampuan untuk mengambil keputusan inovatif

Teori Motivasi Vroom (1964) Teori dari Vroom (1964) tentang cognitive theory of motivation menjelaskan mengapa seseorang tidak akan melakukan sesuatu yang ia yakini ia tidak dapat melakukannya, sekalipun hasitentukan oleh tiga komponuen yaitu :

Ekspektasi (harapan) keberhasilan pada suatu tugas Instrumentalis, yaitu penilaian yentang apa yang akan terjadi jika berhasil dalam melakukan suatu tugas (keberhasilan tugas untuk mendapatkan outcome tertentu).Valensi, yaitu respon terhadap outcome seperti perasaan positif, netral, atau negative. Motivasi tinggi jika usaha menghasilkan sesuatu yang melebihi harapan. Motivasi rendah jika usahanya menghasilkan kurang dari yang diharapkan.

Teori Achievement McClelland (1961)

Teori dari Mc Clelland (1961) yang mengemukkan menyatakan bahwa ada tiga hal penting yang menjadi kebutuhan manusia yaitu :

Need of achievement (Kebutuhan akan prestasi)

Need of affiliation (Kebutuhan akan hubungan social / hampir sama dengan social neednya Maslow) Need of power (dorongan untuk mengatur)

Teori Motivasi Erg Clayton Alderfer. Clayton Alderfer ERG mengetengahkan teori Motivasi ERG yang didasarkan pada kebutuhan manusa akan keberadaan (exsistence), hubungan (relatedness) dan pertumbuhan (growth). Teori ini sedikiy berbeda dengan teori Maslow, disini Clayton Alderfer mengemukakan bahwa jika kebutuhan yang lebih tinggi tidak atau belum dapat dipenuhi maka manusia akan kembali pada gerak yang flesibel dari pemenuhan kebutuhan dari waktu ke waktu dan dari situasi ke situasi.

Pengertian kinerja dalam bahasa Indonesia dari kata dasar "kerja" yang menterjemahkan kata dari bahasa asing prestasidan bisa juga diartikan sebagai hasil kerja. Pengertian kinerja dalam organisasi merupakan jawaban dari berhasil atu tidaknya tujuan organisasi yang telah ditetapkan.

Kinerja karyawan adalah hasil yang dicapai karyawan dengan adanya kemampuan dan perbuatan dalam situasi dan periode tertentu menurut Hukuran yang berlaku untuk pekerjaan yang bersangkutan. Menurut Anwar Prabu Mangkunegara (2005) kinerja (Prestasi Kerja) adalah hasil kerja secara kualitas dan kuantitas yang dicapai oleh seorang karyawan dalam melaksanakan tugasnya sesuai dengan tanggung jawab yang diberikan kepadanya. 
Menurut Martoyo, (2007), kinerja karyawan adalah hasil kerja selama periode tertentu dibandingkan dengan berbagai kemungkinan, misalnya standart, target/sasaran atau criteria yang telah disepakati bersama. Kinerja adalah hasil yang diinginkan dari perilaku kinerja individu merupakan dasar dari kinerja organisasi. Penilaian kinerja mempunyai peranan penting dalam peningkatan motivasi ditempat kerja. Penilaian kinerja ini (performance appraisal) pada dasarnya merupakan factor kunci guna megembangkan suatu organisasi secara efektifdan efesien. Karyawan menginginkan dan memerlukan balikan berkenaan dengan prestasi mereka jika kinerja tidak sesuai dengan standart,maka penilaian memberikan kesempatan untuk meninjau kemajuan karyawan dan untuk menyusun rencana peningkatan kinerja.

Hasibuan (2001) mengemukakan " kinerja (prestasi kerja) adalah suatu hasil kerja yang dibebankan kepadanya yang didasarkan atas kecakapan, pengalaman dan kesungguhan serta waktu. Menurut Veizal Rivai (2004) mengemukakan kinerja adalah : " merupakan perilaku yang ditampilkan setiap orang sebagai prestasi kerja yang dihasilkan oleh karyawan sesuai dengan perannya dalam perusahaan", Menurut Robert L. Mathis dan John H. Jakcson terjemahan Jimmy Sadeli dan Bayu Prawira (2002) menyatakan bahwa "Kinerja pada dasarnya adalah apa yang dilakukan dan tidak dilakukan karyawan". Kata kinerja (performance) dalam konteks tugas, sama dengan prestasi kerja. Para pakar banyakmemberikan definisi tentang kinerja secara umum, dan dibawah ini disajikan beberapa diantaranya :

Kinerja adalah catatan tentang hasil-hasil yang diperoleh dari fungsi- fungsi pekerjaan atau kegiatan tertentu selama kurun waktu tertentu. Kinerja adalah Keberhasilan sesorang dalam melaksanakan suatu pekerjaan. Kinerja mengandung dua komponen penting yaitu :

a. Kompetensi berarti individu atau organisasi memiliki kemampuan untuk mengidentifikasikan tingkat kinerjanya.

b. Produktifitas : Kompetensi tersebut diatas dapat diterjemahkan ke dalam tindakan atau kegiatankegiatan yang tepat untuk mencapai hasil kinerja (outcome).

Ada 5 (lima) factor dalam penilaian Kinerja yaitu :

a. Kualitas pekerjaan meliputi: akuisi, ketelitian, penampilan dan penerimaan keluaran;

b. Kuantitas pekerjaan melipui : Volume keluaran dan kontribusi;

c. Supervisi yang diperlukan, meliputi : membutuhkan saran, arahan atau perbaikan;

d. Kehadiran meliputi : regularitas, dapat dipercaya diandalkan dan ketepatan waktu;

e. Konservasi meliputi : pencegahan, pemborosan, kerusakan dan pemeliharaan.

Ada 3 (tiga) factor yang berpengaruh terhadap kinerja seseorang antara lain :

a. Faktor individu : kemampuan, ketrampilan, latar belakang keluarga, pengalaman tingkat social dan demografi seseorang;

b. Faktor psikologis : persepsi, peran, sikap, kepribadian, motivasi dan kepuasan kerja;

c. Faktor organisasi : struktur organisasi, desain pekerjaan, kepemimpinan, system penghargaan (reward system).

Penilaian kinerja (performance appraisal pada dasarnya merupakan factor kunci guna mengembangkan suatu organisasi secara efektif dan efesien, karena adanya kebijakan atau program yang lebih baik atas sumber daya manusia yang ada dalam organisasi. Penilaian kinerja individu sangat bermanfaat bagi dinamika pertumbuhan organisasi secara keseluruhan, melalui penilaian tersebut maka dapat diketahui kondisi sebenarnya tentang bagaimana kinerja karyawan. Penilaian kinerja adalah cara mengukur kontribusi individu (karyawan) kepada organisasi tempat mereka bekerja.

Menurut Henry Simamora (2004) "Penilaian kinerja adalah proses yang dipakai oleh organisasi untuk mengevaluasi pelaksanaan kerja individu karyawan". Tujuan Penilaian Kinerja Menurut Syafarudin Alwi (2001) secara teoritis tujuan penilaian dikategorikan sebagai suatu yang bersifat yang bersifat evaluation dan development yang bersifat evalution harus menyelesaikan : 
a. Hasil penilaian digunakan sebagai dasar pemberian kompensasi.

b. Hasil penilaian digunakan sebagai staffing decision.

c. Hasil penilaian digunakan sebagai dasar mengevaluasi system seleksi.

Sedangkan yang bersifat development penilai harus menyelesaikan:

a. Prestasi riil dicapai individu

b. Kelemahan - kelemahan individu yang menghambat kinerja.

c. Prestasi -prestasi yang dikembangkan.

Manfaat penilaian kinerja kontribusi hasil-hasil penilaian merupakan suatu yang sangat bermanfaat bagi perencanaan kebijakan organisasi adapun secara terperincu oenilaian kinerja bagi organisasi adalah :

a. Penyesuaian - penyesuaian kompensasi.

b. Perbaikan kinerja.

c. Kebutuhan latihan dan pengembangan.

d. Pengambilan keputusan dalam hal penempatan promosi, mutasi, pemecatan, pemberhentian, dan perencanaan tenaga kerja.

e. Untuk kepentingan penelitian karyawan

f. Membantu diaknosis terhadap kesalahan desain karyawan .

Kerangka Pemikiran adalah suatu model yang menerangkan bagaimana hubungan suatu teori dengan faktor-faktor yang penting tertentu. Kerangka konseptual akan menghubungkan secara teoritis antara variabel penelitian, yaitu variabel bebas dan variabel terikat.

Secara umum hipotesa berasal dari kata hipo (lebih) dan tesis (pernyataan), yaitu suatu pernyataan yang masih lemah dan memerlukan suatu pembuktian untuk menegaskan apakah hipotesis tersebut dapat diterima atau ditolak berdasarkan fakta atau data empiris yang telah dikumpulkan di dalam penelitian. Hipotesa adalah dugaan logis sementara terhadap satu kemungkinan pemecahan masalah yang dapat diterima sebagai kebenaran bilamana dapat dibuktikan validasinya setelah melakukan pengujian fakta-fakta.

Berdasarkan uraian tersebut di atas maka disusun hipotesa sebagai berikut :

a. Terdapat pengaruh yang signifikan antara Motivasi (X1) dengan Kinerja Karyawan (Y)

b. Terdapat pengaruh yang signifikan antara Kepemimpinan (X2) dengan Kinerja Karyawan (Y)

c. Terdapat pengaruh secara bersama-sama Motivasi (X1) dan Kepemimpinan (X2) berpengaruh signifikan dengan Kinerja Karyawan (Y).

\section{METODE PENELITIAN}

Lokasi penelitian yang akan dilaksanakan di PT. Bank BTN Cabang Batam. Populasi diartikan sebagai seluruh anggota kelompok yang sudah ditentukan karakteristiknya dengan jelas, baik itu kelompok orang, objek, atau kejadian. Populasi dalam penelitian ini adalah karyawan PT. Bank BTN Cabang Batam sebanyak 50 orang. Penelitian ini menggunakan metode sensus, yaitu mendata keseluruhan populasi yang ada. Berdasarkan sensus di lapangan maka sampel dalam penelitian ini adalah seluruh karyawan di PT. Bank BTN Cabang Batam sebanyak 50 orang.

Variabel Kepemimpinan: Definisi Konseptual yaitu cara pemimpin untuk mempengaruhi bawahannya. Definisi Operasional yaitu cara pemimpin untuk mempengaruhi bawahannya yang diukur dengan orientasi direktif, orientasi supportive, dan orientasi partisipatif. Indikator Penelitian dengan memperhatikan definisi konseptual dan defenisi operasional. Maka disusun indicator variabel kepemimpian adalah sebagi berikut : Memberikan penugasan, Memberikan dorongan, Memberikan bimbingan, Memberikan kewenangan

Variabel Motivasi. Definisi Konseptual yaitu dorongan yang tumbuh dalam diri seseorang, baik yang berasal dari dalam dan luar dirinya untuk melakukan suatu pekerjaan dengan semangat tinggi menggunakan semua 
kemampuan dan ketrampilan yang dimilikinya. Definisi Operasional yaitu dorongan yang tumbuh dalam diri seseorang, baik yang berasal dari dalam dan luar dirinnya untuk melakukan suatu pekerjaan dengan semangat tinggi menggunakan semua kemampuan dan ketrampilan yang dimilikinya yang diukur dengan kebutuhan fisik, kebutuhan keselamatan, kebutuhan berkelompok, kebutuhan akan penghargaan, dan kebutuhan aktualisasi diri.

Indikator Penelitian dengan memperhatikan definisi konseptual dan definisi operasional, maka disusun indicator variabel motivasi adalah sebagi berikut : Kebutuhan Fisik, Kebutuhan Keselamatan, Kebutuhan Kelompok, Kebutuhan Akan Penghargaan, Kebutuhan Aktualisasi Diri

Variabel Kinerja Karyawan, Definisi Konseptual yaitu hasil yang dicapai oleh karyawan dalam menyelesaikan tugasnya secara efektif dan efesien. Definisi Operasional yaitu hasil yang dicapai oleh karyawan dalam menyelesaikan tugasnya secara efektif dan efisien yang diukur dengan efisien dan efektifitas, otoritas dan tanggung jawab, disiplin dan insiatif. Indikator Penelitian dengan memperhatikan defninisi kon septual dan definisi operasionall, maka disusun indicator variabel kinerja karyawan adalah sebagai berikut : Efetifitas dan Efesiensi, Orientasi dan tanggung jawab, Disiplin, Inisiatif

\section{TEKNIK PENGUMPULAN DATA}

Data Primer yaitu data yang diperoleh dari pihak pertama atau responden langsung. Data ini terdiri dari data kepemimpinan yang terdiri dari dua variabel yaitu Variabel Kepemimpinan (X1) dan Variabel Motivasi (X2)yang berpengaruh sangat signifikan terhadap Kinerja Karyawan (Y).

Observasi: Melakukan pengamatan langsung dan melakukan pengumpulan data melalui penyebaran kuesioner kepada PT. Bank BTN Cabang Batam.

Wawancara: Memberikan pertanyaan kepada pimpinan perusahaan dan karyawan dalam rangka memperkuat data yang sudah dikumpulkan.

Data sekunder yaitu data yang diperoleh dari pihak kedua atau lebih. Melakukan studi pustaka dengan membaca seperti referensi, surat kabar, majalah serta buku catatan selama perkuliahan dan lain-lainnya yang berhubungan dengan penulisan ini. Setelah ditentukan skor dari masing-masing pertanyaan, maka dilakukan pengujian dengan menggunakan uji validitas dan reliabilitas.

Uji Validitas, Untuk menguji validitas instrument penelitian digunakan analisis butir, yaitu dengan cara mengkorelasikan skor masing-masing pertanyaan denganskor total. Teknik yang dilakukan adalah teknik yang dikemukakan oleh Pearson yakni Teknik Kolerasi "product moment" yang dirumuskan sebagai berikut : (Singarimbun, 1989)

$\mathrm{rXY}=$ Koefisien korelasi antara variabel $\mathrm{X}$ dan Variabel $\mathrm{Y}$

2 variabel yang dikorelasikan.

$\sum \mathrm{XY}=$ Jumlah perkalian $\mathrm{X}$ dan $\mathrm{Y}$

$\mathrm{X}=$ Skor masing-masing pertanyaan / item instrument.

$\mathrm{Y} \quad=$ Skor total

$\mathrm{XY} \quad=$ Skor instrument dari tiap dikalikan skor total

Uji Reliabilitas, Adapun Uji Reliabilitas adalah indek yang menunjukan sejauh mana alat pengukuran dapat dipercaya dan dapat diandalkan. Dalam pengukuran gejala social selalu diukur kesalahan pengukuran yang sebenarnya. Kesalahan pengukuran ini sangat diperhitungkan. Rumus untuk menghitungnya sebagai berikut :

$\mathrm{Xo}=\mathrm{Xt}+\mathrm{Xe}$ 
Keterangan :

$$
\begin{array}{ll}
\mathrm{Xo} & =\text { Angka yang diperoleh } \\
\mathrm{Xt} & \quad=\text { Angka yang sebenarnya } \\
\mathrm{Xe} & =\text { Kesalahan pengukuran }
\end{array}
$$

\section{TEKNIK ANALISA DATA}

Pada dasarnya data-data yang diperoleh, dianalisis secara kuantitatif dengan menggunakan model statistic parametik, dalam program computer SPSS (Statistical Productand Service Solution) seperti analisis deskriptif dan regresi berganda. Namun sebelum analisis itu dilalui maka proses yang harus dilakukan adalah melakukan uji validasi dan reabilitas instrument. Apabila telah memenuhi syarat uji tersebut, maka berikutnya dilakukan perhitungkan analisis SPSS ini, selanjutnya diadakan interprestasi terhadap hasil analisis tersebut.

Analisis Deskriptif, digunakan untuk menerangkan informasi mengenai responden, serta untuk mengetahui kepemimpinan dan motivasi terhadap kinerja yang berkembang di PT. Bank BTN Cabang Batam.

Analisi Regresi Linier Berganda (Multi Regression Linier Analysis) digunakan untuk membuat prediksi terhadap kinerja Karyawan PT. Bank BTN Cabang Batam. Penggunaan analisi linier berganda ini dilandasi oleh pertimbangan data yang berskala interval lebih dari satu variabel bebas dengan satu variabel bebas dengan satu variabel terikat, dengan rumus sebagai berikut :

$\mathrm{Y}=\mathrm{a}+\mathrm{b}_{1} \mathrm{X}_{1}+\mathrm{b}_{2} \mathrm{X}_{2}+\ldots \ldots \mathrm{e}$

Keterangan :

Y $\quad=$ Variabel Kinerja Karyawan

X1 = Variabel Kepemimpinan

X2 = Variabel Motivasi

$\mathrm{a}=$ Konstanta

b1 dan b2 = Intercept / koefisien regrisi X1 dan X2

e $\quad=$ Kesalahan Pengganggu

Nilai koefesien a, b dan seterusnya dicari dan analisis dengan menggunakan program SPSS (Statistical Product and Service Solutions). Dalam pengujian hipotesis diambil suatu ketentuan antara diterima atau ditolak, dengan tingkat uji kepercayaan 0.05. Pengambilan keputusan dilakukan berdasarkan nilai uji F dan uji T masingmasing koefisien regresi pada kurva normal yang digunakan dalam penentuan nilai kritis. Jika telat $\mathrm{F}$ tes suatu koefiien regresi daerah penerima Ho. Artinya koefisien regresi tersebut tidak boleh berbeda dengan nol. Dengan kata lain variabel tersebut tidak ada pengaruh terhadap nilai variabel terkait. Sedangkan jika suatu pengujian tersebut suatu koefisien regresi $\mathrm{F}$ tes terletak didaerah penolakan $\mathrm{Ho}$ dan menerima $\mathrm{H}_{1}$, artinya variabel bebas tersebut berpengaruh terhadap nilai variabel terkait.

Sedangkan besarnya pengaruh semua variabel bebas terhadap variabel terikat dapat diketahui dari besarnya koefisien determinan $\left(\mathrm{R}^{2}\right)$ persamaan regresi. Besarnya koefisien determinan dari 0 sampai dengan 1 . Semakin mendekati angka 0, besarnya koefisien determinan suatu persamaan regresi, maka semakin kecil pula pengaruh semua variabel bebas terhadap variabel terikat. 


\section{HASIL PENELITIAN DAN PEMBAHASAN}

\section{Statistik Deskriptif}

Sesuai dengan tujuan dalam penelitian ini, yaitu menguji pengaruh kepemimpinan dan motivasi kerja terhadap kinerja karyawan, maka digunakan kuesioner sebagai alat pengumpulan data (lampiran).

Uji validitas adalah untuk mengetahui tingkat kesahihan tiap butir pertanyaan dalam angket (kuesioner). Uji validitas dilakukan terhadap seluruh butir pernyataan dalam instrumen, yaitu dengan cara mengkorelasikan skor tiap butir dengan skor totalnya pada masing-masing konstruk. Teknik korelasi yang digunakan adalah korelasi product moment Pearson dengan pengujian dua arah (two tailed test). Data diolah dengan bantuan program SPSS for Windows release 20.0 dan perhitungan selengkapnya dapat dilihat pada Lampiran 4 .

Hasil uji validitas dijabarkan pada tabel 5.1 berikut ini:

\begin{tabular}{|c|c|c|c|c|c|}
\hline $\begin{array}{c}\text { Vari } \\
\text { abel }\end{array}$ & Item & $\begin{array}{c}\text { Nilai } \\
\text { Korelasi } \\
\left(\mathrm{r}_{\text {hitung }}\right.\end{array}$ & $\begin{array}{c}\mathrm{r}_{\text {tabel }} \\
(\alpha=5 \%)\end{array}$ & $\begin{array}{c}\text { Penguji } \\
\text { an }\end{array}$ & $\begin{array}{c}\text { Keterang } \\
\text { an }\end{array}$ \\
\hline & $\mathrm{X}_{1.1}$ & 0,43655 & & & Valid \\
$\mathrm{X}_{1}$ & $\mathrm{X}_{1.2}$ & 0,5491 & & Valid \\
& $\mathrm{X}_{1.3}$ & 0,5500 & 0,279 & $\mathrm{r}_{\text {hitung }}>$ & Valid \\
& $\mathrm{X}_{1.4}$ & 0,4903 & & $\mathrm{r}_{\text {tabel }}$ & Valid \\
& $\mathrm{X}_{1.5}$ & 0,4960 & & & Valid \\
& $\mathrm{X}_{1.6}$ & 0,6831 & & & Valid \\
& $\mathrm{X}_{1.7}$ & 0,6235 & & & Valid \\
& $\mathrm{X}_{1.8}$ & 0,5194 & & & Valid \\
\hline & $\mathrm{X}_{2.1}$ & 0,4985 & & & Valid \\
& $\mathrm{X}_{2.2}$ & 0,4855 & & & Valid \\
$\mathrm{X}_{2}$ & $\mathrm{X}_{2.3}$ & 0,4907 & 0,279 & $\mathrm{r}_{\text {hitung }}>$ & Valid \\
& $\mathrm{X}_{2.4}$ & 0,5279 & & $\mathrm{r}_{\text {tabel }}$ & Valid \\
& $\mathrm{X}_{2.5}$ & 0,6990 & & & Valid \\
& $\mathrm{X}_{2.6}$ & 0,5874 & & & Valid \\
\hline & $\mathrm{Y}_{1}$ & 0,4171 & & & Valid \\
& $\mathrm{Y}_{2}$ & 0,4628 & & & Valid \\
$\mathrm{Y}$ & $\mathrm{Y}_{3}$ & 0,6720 & 0,279 & $\mathrm{r}_{\text {hitung }}>$ & Valid \\
& $\mathrm{Y}_{4}$ & 0,5449 & & $\mathrm{r}_{\text {tabel }}$ & Valid \\
& $\mathrm{Y}_{5}$ & 0,5630 & & & Valid \\
\hline
\end{tabular}


Dari hasil uji validitas seperti yang disajikan pada tabel menunjukkan bahwa semua nilai $\mathrm{r}_{\text {hitung }}$ lebih besar dari $r_{\text {tabel }}(0,279)$ pada taraf signifikansi $5 \%$. Artinya tiap pernyataan berkorelasi dengan skor skor totalnya dan data yang dikumpulkan dinyatakan valid (sahih) dan siap untuk dianalisis.

Uji reliabilitas digunakan untuk mengetahui sejauh mana suatu alat pengukur dapat dipercaya atau dapat diandalkan dan tetap konsistem jika dilakukan dua kali pengukuran atau lebih pada kelompok yang sama dengan alat ukur yang sama. Pengujian Cronbach Alpha digunakan untuk menguji tingkat keandalan (reliability) dari masing-masing angket variabel. Apabila nilai Cronbach Alpha semakin mendekati 1 mengidentifikasikan bahwa semakin tinggi pula konsistensi internal reliabilitasnya.

Hasil uji reliabilitas memperoleh nilai koefisien reliabilitas $\left(\mathrm{r}_{11}\right)$ yang lebih besar dari 0,6. Sesuai dengan pendapat Ghozali (2001) bahwa pernyataan dinyatakan reliabel (handal) jika nilai Cronbach Alpha lebih besar dari 0,6. Jadi dapat dinyatakan bahwa seluruh pernyataan dalam kuesioner adalah reliabel (dapat diandalkan).

\section{ANALISIS DATA}

Uji normalitas dalam penelitian ini digunakan untuk mengetahui apakah data memiliki sebaran yang normal. Untuk menguji normalitas data dalam penelitian ini digunakan uji Kolmogorov-Smirnov. Kemudian untuk menerima atau menolak hipotesis dengan cara membandingkan p-value dengan taraf signifikansi $(\alpha)$ sebesar 0,05. Jika p-value >0,05, maka data berdistribusi normal. Dari hasil perhitungan uji Kolmogorov-Smirnov, dapat diketahui bahwa p-value dari unstandardized resdiual ternyata lebih besar dari $\alpha$ $(\mathrm{p}>0,05)$, sehingga keseluruhan data tersebut dinyatakan memiliki distribusi normal atau memiliki sebaran data yang normal.

Uji multikolinearitas digunakan untuk mengetahui apakah ada korelasi di antara variabel independen yang satu dengan yang lainnya. Hasil uji multikolinieritas dapat dilihat dari besarnya Tolerance Value dan Variance Inflation Factor (VIF). Dari hasil perhitungan menunjukkan bahwa semua variabel bebas yang memiliki tolerance lebih dari 0,1 $(>0,1)$ dan semua variabel bebas memiliki nilai VIF kurang dari 10 (Ghozali, 2001). Jadi dapat disimpulkan bahwa tidak ada gejala multikolinieritas dalam model regresi.

Uji heteroskedastisitas digunakan untuk mengetahui apakah dalam model regresi memiliki variansi yang sama (homoskedastisitas) dari residual satu ke pengamatan yang lain. Jika asumsi ini tidak dipenuhi, maka terjadi heteroskedastisitas. Dari hasil perhitungan tersebut menunjukkan tidak ada gangguan heteroskedastisitas, karena nilai thitung lebih kecil dari nilai $t_{\text {tabel }}$ dengan nilai $\mathrm{p}>0,05$ atau tidak signifikan. Secara keseluruhan dapat disimpulkan bahwa tidak ada masalah heteroskedastisitas dalam penelitian ini (Ghozali, 2001).

Analisis regresi dalam penelitian ini digunakan untuk menguji pengaruh kepemimpinan dan motivasi kerja terhadap kinerja karyawan. Penyelesaian model regresi linier berganda dilakukan dengan bantuan Program SPSS for Windows Release 20.0

Dari hasil analisis regresi di atas, maka dapat disusun persamaan sebagai berikut:

$$
\mathrm{Y}=-12,777+0,485 \mathrm{X} 1+0,627 \mathrm{X} 2
$$

Persamaan menunjukkan bahwa kinerja karyawan dipengaruhi oleh kepemimpinan dan motivasi kerja. Nilai konstanta sebesar -12,777 menyatakan jika tidak ada peningkatan kepemimpinan dan motivasi kerja, maka skor kinerja berkurang sebesar 12,777 satuan. Nilai koefisien kepemimpinan sebesar 0,48 menyatakan jika terjadi peningkatan kepemimpinan sebesar satu satuan maka kinerja karyawan akan mengalami 
peningkatan sebesar 0,485 satuan. Nilai koefisien motivasi kerja sebesar 0,627 menyatakan jika terjadi peningkatan motivasi kerja sebesar satu satuan maka kinerja karyawan akan mengalami peningkatan sebesar 0,627 satuan.

Uji F digunakan untuk mengetahui signifikansi dari model regresi yang digunakan. Cara yang digunakan adalah dengan membandingkan $\mathrm{F}_{\text {hitung }}$ dengan $\mathrm{F}_{\text {tabel }}$ pada taraf signifikansi $(\alpha)=5 \%$.

Dari hasil pengolahan data diperoleh $\mathrm{F}_{\text {hitung }}=50,996$, sedangkan $\mathrm{F}_{\text {tabel }}$ pada taraf signifikansi 5\% dengan df $(2 ; 47)$ adalah sebesar 3,23. Dikarenakan $F_{\text {hitung }}>F_{\text {tabel }}(50,996>3,23)$, artinya model regresi tentang pengaruh kepemimpinan dan motivasi kerja terhadap kinerja karyawan sudah signifikan. Hal ini menunjukkan bahwa kepemimpinan dan motivasi kerja secara simultan berpengaruh terhadap kinerja karyawan.

Koefisien determinasi menyatakan persentase total variasi dari variabel dependen yang dapat dijelaskan oleh variabel independen dalam model. Nilai $\mathrm{R}^{2}$ berkisar antara 0 sampai 1 . Apabila $\mathrm{R}^{2}$ mendekati 1 , ini menunjukkan bahwa variasi variabel dependen dapat dijelaskan oleh variasi variabel independen. Sebaliknya jika nilai $\mathrm{R}^{2}$ mendekati 0 , maka variasi dari variabel dependen tidak dapat dijelaskan oleh variabel independen (Ghozali, 2001).

Dari pengujian yang telah dilaksanakan menghasilkan nilai koefisien determinasi $\mathrm{R}^{2}$ sebesar 0,685 (perhitungan selengkapnya dapat dilihat pada Lampiran 11), sehingga dapat dikatakan bahwa hasil pengujian yang dilakukan memberikan hasil yang baik (goodness of fit). Hal ini menunjukkan bahwa sekitar 68,5\% variasi dari kinerja karyawan dapat dijelaskan oleh variabel kepemimpinan dan motivasi kerja. Sedangkan sekitar 31,5\% lainnya dapat dijelaskan oleh variabel lain diluar model.

Pengujian hipotesis dalam penelitian ini menggunakan uji $\mathrm{t}$ (pengaruh secara individual). Pengujian ini dimaksudkan untuk mengetahui signifikansi dari pengaruh variabel independen terhadap variabel dependen secara individual. Pengujian nilai $t$ dilakukan dengan dua sisi yang digunakan untuk menguji hipotesis. Hasil pengujian diperoleh dari test signifikansi dengan program SPSS for Windows Release 20.0.

Hasil uji $\mathrm{t}$ dapat menunjukkan bahwa variabel kepemimpinan memiliki nilai $t_{\text {hitung }}=4,223$ dengan nilai $\mathrm{p}=0,000$, sedangkan $\mathrm{t}_{\text {tabel }}$ pada taraf signifikansi $5 \%$ adalah $=2,021$. Dikarenakan $t_{\text {hitung }}>\mathrm{t}_{\text {tabel }}(4,223>$ 2,021) dengan $\mathrm{p}<0,05$, maka $\mathrm{H}_{1}$ diterima. Artinya kepemimpinan secara statistik berpengaruh terhadap kinerja karyawan.

Variabel motivasi kerja memiliki nilai $\mathrm{t}_{\text {hitung }}=6,329$ dengan nilai $\mathrm{p}=0,000$, sedangkan $\mathrm{t}_{\text {tabel }}$ pada taraf signifikansi $5 \%$ adalah $=2,021$. Dikarenakan $t_{\text {hitung }}>t_{\text {tabel }}(6,329>2,021)$ dengan $p<0,05$, maka $\mathrm{H}_{2}$ diterima. Artinya motivasi kerja secara statistik berpengaruh terhadap kinerja karyawan.

Hasil pengujian hipotesis pertama dengan uji t memperoleh nilai thitung $=4,223$ diterima pada taraf signifikansi $5 \%(\mathrm{p}<0,05)$. Artinya kepemimpinan berpengaruh positif dan signifikan terhadap kinerja karyawan. Semakin baik kepemimpinan transformasional yang dijalankan, maka kinerja karyawan akan meningkat. Sebaliknya semakin kurang baik kepemimpinan yang dijalankan, maka kinerja karyawan juga akan semakiin berkurang. Kepemimpinan merupakan kepemimpinan yang sungguh bekerja menuju sasaran pada tindakan mengarahkan organisasi kepada suatu tujuan yang tidak pernah diraih sebelumnya. Para pemimpin secara riil harus mampu mengarahkan organisasi menuju arah baru. Kepemimpinan melibatkan perubahan dalam organisasi yang membutuhkan tindakan memotivasi para bawahan agar bersedia bekerja demi sasaran-sasaran tingkat tinggi yang dianggap melampaui kepentingan pribadinya pada saat itu.

Hasil penelitian ini berhasil mendukung hipotesis $\mathrm{H}_{1}$ bahwa kepemimpinan berpengaruh positif dan signifikan terhadap kinerja karyawan. Konsisten dengan hasil penelitian 
sebelumnya oleh Utami (2006) yang membuktikan kepemimpinan berpengaruh positif terhadap kinerja karyawan.

Hasil pengujian hipotesis kedua dengan uji $\mathrm{t}$ memperoleh nilai $\mathrm{t}_{\text {hitung }}=6,329$ diterima pada taraf signifikansi 5\% $(\mathrm{p}<0,05)$. Artinya motivasi kerja berpengaruh positif dan signifikan terhadap kinerja karyawan. Semakin tinggi motivasi kerja karyawan, maka kinerja akan semakin meningkat. Sebaliknya semakin rendah motivasi kerja karyawan, maka kinerja karyawan juga akan semakin berkurang. Kinerja karyawan akan meningkat jika karyawan memiliki motivasi atau dorongan untuk bekerja yang tinggi. Motivasi atau dorongan untuk bekerja dapat ditingkatkan dengan rangsangan-rangsangan insentif (hadiah) bagi yang berprestasi. Manajer atau pimpinan perusahaan dapat memotivasi (merangsang bawahannya) dengan berupa pemberian hadiah kepada mereka yang berprestasi. Hadiah tersebut tentunya disesuaikan dengan kebutuhan mendesak karyawan. Dengan motivasi positif ini semangat bekerja bawahan akan meningkat. Sebab tingkah laku atau tindakan masingmasing individu pada suatu saat tertentu, biasanya ditentukan oleh kebutuhan yang mendesak. Oleh karena itu setiap manajer yang ingin memotivasi bawahannya perlu memahami hierarki daripada kebutuhan-kebutuhan manusia.

Hasil penelitian ini berhasil mendukung hipotesis $\mathrm{H}_{2}$ bahwa motivasi kerja berpengaruh positif dan signifikan terhadap kinerja karyawan. Konsisten dengan hasil penelitian sebelumnya oleh Utami (2006) yang membuktikan motivasi kerja berpengaruh positif terhadap kinerja karyawan.

\section{KESIMPULAN}

Dari hasil analisis data dan pembahasan dapat diambil simpulan sebagai berikut:

1. Variabel kepemimpinan dan motivasi kerja secara simultan berpengaruh signifikan terhadap kinerja karyawan PT. Bank BTN Batam. Dari hasil pengolahan data diperoleh $F_{\text {hitung }}=50,996$, sedangkan $F_{\text {tabel }}$ pada taraf signifikansi 5\% dengan df $(2 ; 47)$ adalah sebesar 3,23. Dikarenakan $F_{\text {hitung }}>F_{\text {tabel }}(50,996>$ 3,23), artinya model regresi tentang pengaruh kepemimpinan dan motivasi kerja terhadap kinerja karyawan sudah signifikan. Hal ini menunjukkan bahwa kepemimpinan dan motivasi kerja secara simultan berpengaruh terhadap kinerja karyawan.

2. Kepemimpinan berpengaruh positif terhadap kinerja karyawan PT. Bank BTN Batam. Hal ini terbukti dari hasil uji t memperoleh nilai $\mathrm{t}_{\text {hitung }}$ sebesar 4,223 diterima taraf signifikansi $5 \%(\mathrm{p}<0,05)$ dan $\mathrm{H}_{1}$ diterima. Artinya semakin baik kepemimpinan yang dijalankan, maka kinerja karyawan akan meningkat.

3. Motivasi kerja berpengaruh positif terhadap kinerja karyawan PT. Bank BTN Batam. Hal ini terbukti dari hasil uji $\mathrm{t}$ memperoleh nilai $\mathrm{t}_{\text {hitung }}$ sebesar 6,329 diterima taraf signifikansi 5\% (p<0,05) dan $\mathrm{H}_{2}$ diterima. Artinya semakin tinggi motivasi kerja karyawan, maka kinerjanya akan semakin meningkat.

Dari hasil penelitian, analisis data, pembahasan dan kesimpulan yang telah diambil, maka dapat dikemukakan saran sebagai berikut:

Bagi penelitian mendatang hendaknya sampel dan daerah penelitian lebih diperluas lagi, yaitu tidak terbatas pada karyawan PT. Bank BTN Batam, namun dilakukan survey pada lebih dari satu dinas, sehingga tingkat generalisasinya lebih baik.

Bagi penelitian mendatang hendaknya instrumen penelitian lebih diperdalam dan dikembangkan lagi sehingga kemampuan mengukurnya lebih baik. Karena pada dasarnya masih banyak faktor-faktor lain yang mempengaruhi kinerja karyawan.

\section{DAFTAR PUSTAKA}


Buhler, Particia, 2004. Alpha Teach Your Self Management Skiils, Edisi Pertama

Sugeng Haryanto, Sukono Mukidi dan M. Rudi Atmoko, Jakarta :

Prenada.

Djarwanto Ps dan Pangestu Subagyo,1993. Statistik Induktif .Edisi keempat. Yogyakarta:BPFE

Flippo, Edwin B. Masud Moh (alih bahasa),1990.Manajemen Personalia. Edisi Keenam. Jilid Kedua.Jakarta : Erlangga

Ghozali, Imam, 2005. Aplikasi Analisis Multivariate Dengan Program SPSS. Edisi 3

Hasibuan, Sayuti, 2000. Manajemen Sumber Daya Manusian Non Sekuler, Muhammadiyah Universitas Press, Surabaya.

Hasibuan, Malayu S.P. 2008. Manajemen Dasar, Pengertian dan Masalah, Bumi Aksara : Jakarta.

Heidrajrahcman dan Husnan Suad.2000, Manajemen Personalia, BPFE, Yogyakarta

Kartono, Kartini. 1983. Pemimpin dan Kepemimpinan. Jakarta : Rajawali

Mangkunegara, A.A. Anwar Prabu. 2005. Evaluasi Kinerja SDM. Bandung: Rafika Aditama.

Martoyo, Susilo. 2007. Manajemen Sumber Daya Manusia. Edisi Kelima. Yogyakarta : BPFE

Mathis, Robert L dan John H Jackson, 2002.Manajemen Sumber Daya Manusia.Buku 2 Jilid Pertama. Jakarta : Salemba Empat

Nawawi H. Hadari dan martini H. Mimi,1994. Metode Diskriptif Penelitian

Terapan. Yogyakarta : UGM Press

O’Leary, Elizabeth. 2001. Kepemimpinan. Edisi Pertama. Yogyakarta : Andi

Robbin, Stephen. 2008, Perilaku Organisasi Edisi 12, salemba Empat : Jakarta

Sevilla, Consuelo G.et.al.1993. Pengantar Metode Penelitian. Penerjemah oleh Alimuddin Tuwu. Jakarta : Universitas Indonesia

Simamora, Henry, 2004. Manajemen Sumber Daya Manusia. Edisi Kedua.STIE : YKPN

Sugiyono. 2008. Metode Penelitian Bisnis, Alfabeta : Bandung

Suranta, Sri 2002. Dampak Motivasi Karyawan Pada Hubungan Antara Gaya Kepemimpinan Dengan Kinerja Karyawan Perusahaan Bisnis, Jurnal Penelitian Ekonomi Bisnis dan Pembangunan Vol 15 No.2 Desember 2002 : 116-138

Utami, Sri.2006. Pengaruh Kepemimpinan Transformasional Dan Motivasi Kerja Terhadap Kinerja Karyawan PT Jati Agung Arsitama Grogol Sukoharjo.Skripsi. Surakarta : UNS. 
Wahjosumidjo. 2004. Kemampuan dan Motivasi . Ghalia Indonesia : Jakarta 